\title{
Differential Regulation of Ciliary Neurotrophic Factor (CNTF) and CNTF Receptor $\alpha$ Expression in Astrocytes and Neurons of the Fascia Dentata after Entorhinal Cortex Lesion
}

\author{
Mun-Yong Lee, ${ }^{\text {a }}$ Thomas Deller, ${ }^{a}$ Matthias Kirsch, Michael Frotscher, and Hans-Dieter Hofmann \\ Institute of Anatomy, University of Freiburg, D-79001 Freiburg, Germany
}

Neurotrophic factors have been implicated in reactive processes occurring in response to CNS lesions. Ciliary neurotrophic factor (CNTF), in particular, has been shown to ameliorate axotomy-induced degeneration of CNS neurons and to be upregulated at wound sites in the brain. To investigate a potential role of CNTF in lesion-induced degeneration and reorganization, we have analyzed the expression of CNTF protein and CNTF receptor $\alpha(\mathrm{CNTFR} \alpha)$ mRNA in the rat dentate gyrus after unilateral entorhinal cortex lesions (ECLs), using immunocytochemistry and nonradioactive in situ hybridization, respectively.

In sham-operated as in normal animals, CNTF protein was not detectable by immunocytochemistry. Starting at $3 \mathrm{~d}$ after ECL, upregulation of CNTF expression was observed in the ipsilateral outer molecular layer (OML). Expression was maximal at around day 7 , and at this stage immunoreactivity could be specifically localized to astrocytes in the ipsilateral OML. By day 14 postlesion, CNTF immunoreactivity had returned to control levels. CNTFR $\alpha$ mRNA was restricted to neurons of the granule cell layer in controls. Three days postlesion, prominent CNTFR $\alpha$ expression was observed in the deafferented OML. A similar but less prominent response was noticed in the contralateral OML. After $10 \mathrm{~d}, \mathrm{CNTFR} \alpha$ expression had returned to control levels. Double labeling for CNTFR $\alpha$ mRNA and glial fibrillary acidic protein (GFAP) showed that upregulation of CNTFR $\alpha$ occurred in reactive, GFAP-immunopositive astrocytes of the OML. A substantial reduction of CNTFR $\alpha$ expression in the deafferented granule cells was transiently observed at 7 and $10 \mathrm{~d}$ postlesion. Our results suggest a paracrine or autocrine function of CNTF in the regulation of astrocytic and neuronal responses after brain injury.

Key words: CNTF; CNTFR $\alpha$; brain injury; dentate gyrus; entorhinal cortex lesions; glial fibrillary acidic protein
Injuries to the CNS result in complex cellular responses at the site of lesion as well as in axotomized and deafferented neurons and in areas of terminal degeneration. Neurotrophic proteins are among the signals that are believed to play an important role in these processes (Longo et al., 1993; Sofroniew and Cooper, 1993; Sendtner et al., 1994). In addition to their role as target-derived factors (Longo et al., 1993; Sofroniew and Cooper, 1993), they have also been implicated in lesion-induced glial responses, both as mediators of astrocyte activation and as astrocyte-derived signals supporting neuronal survival and regenerative processes (Lindsay, 1979; Nieto-Sampedro and Bovolenta, 1990; Lu et al., 1991; Altar et al., 1992; Rudge et al., 1992; Yoshida and Gage, 1992; Eddleston and Mucke, 1993).

Ciliary neurotrophic factor (CNTF) was originally identified as a survival factor for developing peripheral neurons (Manthorpe et al., 1986), but results from subsequent studies suggested that it may be of particular functional importance in the injured mature nervous system (Lindsay et al., 1994; Sendtner et al., 1994). Neuronal targets in the adult CNS have been identified by demonstrating that CNTF attenuates axotomy-induced neuronal de-

Received Sept. 9, 1996; revised Nov. 1, 1996; accepted Nov. 12, 1996.

This work was supported by grants from the Deutsche Forschungsgemeinschaft, SFB 505 (M.K., H.-D.H.), DE 551/5-1 (T.D.), and Leibniz program (M.F.), and the Korean Research Fund of Songeui (M.-Y.L.).

Correspondence should be addressed to Dr. H.-D. Hofmann, Institute of Anatomy

I, P.O. Box 111, D-79001 Freiburg, Germany.

Dr. Lee's present address: Department of Anatomy, Catholic University Medical College, Seoul 137-701, Korea.

${ }^{\text {a }}$ These authors contributed equally to this work.

Copyright (C) 1997 Society for Neuroscience 0270-6474/97/171137-10\$05.00/0 generation (for review, see Manthorpe et al., 1993; Sendtner, 1994). In contrast to neurotrophins, CNTF seems to be expressed exclusively by glial cells, making it unlikely that it acts as a classical target-derived factor (Stöckli et al., 1989, 1991; Dobrea et al., 1992). CNTF expression is high in Schwann cells of adult peripheral nerves and shows marked changes after nerve injury (Stöckli et al., 1989; Friedman et al., 1992; Sendtner et al., 1992; Curtis et al., 1993). In the CNS, CNTF levels are high in the adult optic nerve and olfactory bulb but low in the rest of the brain parenchyma (Stöckli et al., 1991; Ip et al., 1993a); however, a substantial increase of CNTF mRNA and protein levels was observed in CNS tissue immediately bordering a wound site (Ip et al., 1993b; Asada et al., 1995) and in cultured astrocytes that in many respects resemble reactive astrocytes in vivo (Stöckli et al., 1991; Rudge et al., 1992, 1994b).

CNTF effects are mediated by a tripartite receptor complex consisting of two signal-transducing subunits (leukemia inhibitory factor receptor $\beta$, gp130) and a CNTF-specific ligand-binding $\alpha$-subunit (CNTFR $\alpha$ ) (Davis et al., 1993; Stahl et al., 1993). CNTFR $\alpha$ expression was detected exclusively in neurons, in both the developing and adult nervous system (Ip et al., 1993a; Lee et al., 1996; MacLennan et al., 1996); however, the expression of functional CNTF receptors by cultured astrocytes (Rudge et al., 1994a) suggested that glial cells also represent CNTF targets, at least under certain conditions. In line with this suggestion, the appearance of a strong $\operatorname{CNTFR} \alpha$ hybridization signal lining the wound site after an aspiration lesion of the hippocampus was interpreted as injury-induced CNTFR $\alpha$ expression by astrocytes (Rudge et al., 1994a). 
The interpretation of CNTF and CNTFR $\alpha$ changes in lesioned CNS tissue is hampered by the complexity of the processes taking place at wound sites. Therefore, we used a lesion model that allowed us to analyze changes in the expression of CNTF and its receptor under defined conditions at a distance from the lesion site. Entorhinal cortex lesion (ECL) is an established model to analyze terminal degeneration, sprouting, and synapse replacement in the CNS (for review, see Steward, 1991, 1994). ECL causes the loss of $80-90 \%$ of all synapses in the outer molecular layer (OML) of the dentate gyrus, followed by the sprouting of surviving afferent fiber systems that replace up to $80 \%$ of the lost synapses after long survival times (Matthews et al., 1976a,b; Steward and Vinsant, 1983). Our study describes pronounced layerspecific and cell-specific changes in CNTF and CNTFR $\alpha$ expression in the dentate gyrus after ECL.

\section{MATERIALS AND METHODS}

Animals and surgical procedures. Thirty-three adult male Sprague Dawley rats (250-350 gm) housed under standard laboratory conditions were used in this study. All surgical procedures were performed under deep nembutal anesthesia ( $50 \mathrm{mg} / \mathrm{kg}$ body weight). A standard electrocoagulator was used to make a unilateral cut in the frontal and sagittal plane between the entorhinal area and the hippocampus, which resulted in the complete destruction of the ipsilateral entorhinal afferents to the fascia dentata (also see Deller et al., 1995, 1996a,b). The following coordinates measured from the interaural line were used: frontal cut-anteroposterior $(\mathrm{AP})+1$, lateral (L) 3-7, ventral (V) down to the base of the skull; sagittal cut-AP +1 to $+4 ; \mathrm{L} 6.7, \mathrm{~V}$ down to the base of the skull (Paxinos and Watson, 1986). Sham-operated animals were treated in the same way; however, only the cortex was lesioned in these animals. The following groups of animals were analyzed: (1) control animals $(n=3)$; (2) experimental animals [for CNTF-immunocytochemistry, animals were allowed to survive for $2 \mathrm{~d}(n=2)$ and $5 \mathrm{~d}(n=2)$ after ECL; for CNTFR $\alpha$-mRNA in situ hybridization, animals were allowed to survive for $4 \mathrm{hr}(n=2), 3 \mathrm{~d}(n=4), 7 \mathrm{~d}(n=6), 10 \mathrm{~d}(n=2), 14 \mathrm{~d}(n=2), 4$ weeks $(n=2)$, and 6 months $(n=1)$ after ECL]; and (3) sham-operated animals ( $n=1$ for each time point). These animals were processed together with control and experimental animals. Before the dissection of the brains, the animals were anesthetized deeply with an overdose of nembutal and transcardially perfused with a fixative containing $4 \%$ paraformaldehyde in $0.1 \mathrm{M}$ PBS, pH 7.4. The tissue was post-fixed for $4 \mathrm{hr}$ and incubated overnight in $30 \%$ sucrose. Brains were cut coronally $(30 \mu \mathrm{m})$ on a cryostat and processed free-floating for in situ hybridization and immunocytochemistry.

In situ hybridization. For the generation of $\operatorname{CNTFR} \alpha$-specific riboprobes by PCR and in vitro transcription, total RNA was isolated from adult rat retinal tissue, which expresses relatively high levels of the CNTFR $\alpha$ transcript (Chromczynski and Sacchi, 1987; Kirsch and Hofmann, 1994). One microgram was transcribed with $200 \mathrm{U}$ of MurineMoloney Leukemia Virus reverse transcriptase (Life Technologies, Gaithersburg, MD) and oligo (dT)12-18 (Pharmacia, Freiburg, Germany). CNTFR $\alpha$ cDNA was amplified with primers selected from the published sequence of the rat receptor (Ip et al., 1993a) to produce a 350 base pair (bp) fragment (bp 681-1029). After purification from agarose gels, the product was reamplified with a reverse primer to introduce the T7-polymerase promoter sequence. The resulting cDNA was again purified, and $1 \mu \mathrm{g}$ was used for in vitro transcription with T7-polymerase and digoxigenin-labeled UTP according to the manufacturer's instructions (Boehringer Mannheim, Mannheim, Germany). The same strategy (using a modified forward primer) was applied to generate the sense-stranded riboprobe. The antisense probe was routinely used at a dilution of 1:6000, and the sense probe was diluted 1:2000-6000 in control experiments.

Sections from lesioned and control animals were sampled and processed simultaneously to ensure identical hybridization conditions. Samples were washed twice in $2 \times$ SSC $(20 \times$ SSC: $3 \mathrm{M} \mathrm{NaCl}, 0.3$ M sodium citrate, $\mathrm{pH}$ 7.0) and then prehybridized in a solution containing $50 \%$ formamide, $250 \mu \mathrm{g} / \mathrm{ml}$ denatured salmon sperm DNA, $100 \mu \mathrm{g} / \mathrm{ml}$ yeast tRNA, $0.05 \mathrm{M}$ sodium phosphate, $\mathrm{pH} 7.0,4 \times \mathrm{SSC}, 5 \%$ dextran sulfate, and $1 \times$ Denhardt's solution. Sections were then incubated overnight at $57^{\circ} \mathrm{C}$ with antisense or sense probes diluted in hybridization solution, washed in $2 \times \mathrm{SSC}$ at room temperature, and then successively at $67^{\circ} \mathrm{C}$ with prewarmed $2 \times \mathrm{SSC}, 2 \times \mathrm{SSC} / 50 \%$ formamide, $0.1 \times \mathrm{SSC} / 50 \%$ for- mamide, and $0.1 \times \mathrm{SSC}$ for $30 \mathrm{~min}$ each. After several rinses in Trisbuffered saline (TBS; $0.15 \mathrm{M} \mathrm{NaCl}, 0.1 \mathrm{M}$ Tris, $\mathrm{pH} 7.5$ ), the tissue was incubated in blocking solution (Boehringer Mannheim) followed by overnight treatment with alkaline phosphatase-conjugated sheep antidigoxigenin antibody (1:2000; Boehringer Mannheim) at $4^{\circ} \mathrm{C}$. After several rinses in $50 \mathrm{mM} \mathrm{MgCl} 2$ in TBS, pH 9.5, the phosphatase reaction was performed using 4-nitroblue tetrazolium chloride $(0.35 \mathrm{mg} / \mathrm{ml})$ and 5-bromo-4-chloro-3-indoyl phosphate $(0.18 \mathrm{mg} / \mathrm{ml})$ as substrates. Sections were then either processed for GFAP immunocytochemistry in the case of double-labeling experiments (see below) or air-dried on slides and mounted in Kaiser's gelatin.

Immunocytochemistry. Sections were washed three times in phosphate buffer (PB; 0.1 M, pH 7.4), incubated for $1 \mathrm{hr}$ in PB containing 1\% Triton $\mathrm{X}-100$ and $10 \%$ normal goat serum (for GFAP immunocytochemistry) or $10 \%$ normal rabbit serum (for CNTF immunocytochemistry), and then incubated overnight at $4^{\circ} \mathrm{C}$ with primary antibodies diluted in $0.3 \%$ Triton $\mathrm{X}-100$ and $1 \%$ of the appropriate serum. A monoclonal mouse antibody to GFAP (1:50; Boehringer Mannheim) and a goat anti-rat CNTF antibody (1:1000; R\&D, Oxon, UK) were used in the experiments presented here, but identical results were obtained with two monoclonal antibodies to CNTF. The goat antibody, which has been raised against recombinant rat $\mathrm{CNTF}$, recognized a single protein with the molecular weight of rat $\mathrm{CNTF}$ in immunoblots performed with extracts from rat retina and sciatic nerve. Primary antibody binding was visualized using biotinylated rabbit anti-goat antibodies (1:200; Camon, Wiesbaden, Germany) or biotinylated goat anti-mouse antibodies (1:200; Biotrend, Köln, Germany) and ABC Elite kit (Camon) with 3,3'-diaminobenzidine $\left(0.05 \%, 0.01 \% \mathrm{H}_{2} \mathrm{O}_{2}\right.$ in Tris buffer) as detection system.

\section{RESULTS}

\section{Layer-specific upregulation of CNTF protein by ECL}

In agreement with results from Northern blotting (Stöckli et al., 1991) and in situ hybridization experiments (Ip et al., 1993b), immunocytochemistry indicated very low CNTF protein levels in brains of normal animals. Sections stained with goat antiserum to CNTF showed no specific signals and were indistinguishable from controls treated with normal goat serum (Fig. 1a, inset).

Three days after ECL, CNTF immunoreactivity became detectable in the dentate gyrus OML on both sides. In the contralateral OML, staining was weak and not equally visible in all parts of the OML (Fig. 1a). This labeling did not increase during the following days and disappeared with prolonged survival times (see below). Ipsilaterally, the OML was stained much more strongly (Fig. 1b,c). A sharp border delineated the CNTF-positive OML from the immunonegative inner molecular layer (IML). Punctate CNTF immunoreactivity was distributed homogeneously throughout the OML. Occasionally, immunoreactive cell somata were identifiable (Fig. 1c), but at this stage it was not possible to attribute the staining to a specific cell type. With normal goat serum, no increase of immunoreactivity was observed in the deafferented OML, and antisera to other relevant proteins (e.g., GFAP) produced a clearly different staining pattern (data not shown). These control experiments indicated that the layer-specific punctate immunoreactivity $3 \mathrm{~d}$ postlesion reflected an increase in CNTF expression and was not attributable to an increased unspecific binding of antibodies in this area of terminal degeneration.

Seven days postlesion, the pattern of CNTF immunoreactivity was strikingly altered. Numerous heavily CNTF-positive cells were observed in the OML (Fig. 1d,e), and the diffuse staining of the neuropil had returned almost to control levels. The IML was free of CNTF-immunoreactive cells. The distribution pattern and the morphology of the cells in the OML identified them as astrocytes (compare with Fig. 3a,b). Immunoreactivity, although of lower intensity, was still present in astrocytes of the ipsilateral OML at $10 \mathrm{~d}$ postlesion (Fig. $1 f$ ), but it had decreased to control levels after 2 weeks (not shown). In addition to these characteristic changes in immunoreactivity, there was a progressive postle- 

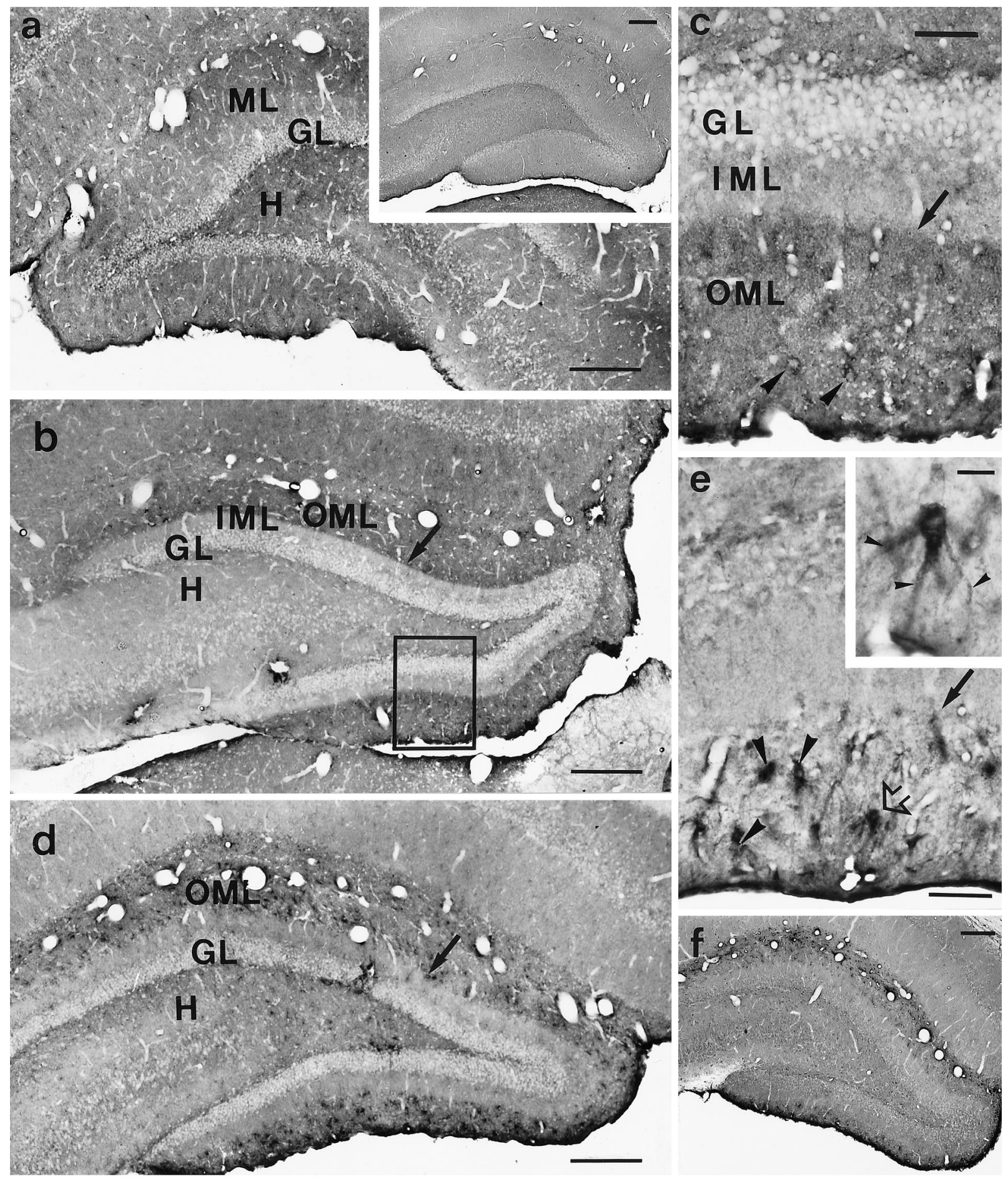

Figure 1. Changes in CNTF immunoreactivity after ECL. $a$, Coronal section of the dentate gyrus contralateral to the lesion immunostained with antibodies to CNTF 3 d postlesion. Sparse CNTF immunoreactivity is visible in some parts of the molecular layer. The inset shows a section from a sham-operated animal processed for CNTF immunocytochemistry under identical conditions. $M L$, Molecular layer; $G L$, granular layer; $H$, hilus. $b$, Dentate gyrus ipsilateral to the lesion $3 \mathrm{~d}$ postlesion. Note the sharp boundary (arrow) between the immunoreactive denervated OML and the unlabeled IML. $c$, Higher magnification of rectangle in $b$. Punctate immunoreactivity is distributed throughout the OML; labeled cellular profiles are rare (arrowheads). The arrow points to the border between the IML and OML. $d$, Dentate gyrus ipsilateral to the lesion $7 \mathrm{~d}$ postlesion. The arrow points to the border between the IML and OML. Note the significant increase in immunoreactivity in the OML and in stratum lacunosum moleculare. $e$, Higher magnification of a serial section of $d$. Note that CNTF immunoreactivity is now localized to processes and somata of cells (arrowheads) that can be identified as astrocytes. The bold arrow points to the border between the IML and OML. The open arrow points to an astrocyte that is shown at higher magnification in the inset, demonstrating labeling of the soma and of long processes (arrowheads). $f$, Ipsilateral dentate gyrus of a lesioned animal $10 \mathrm{~d}$ postlesion. Immunolabeling is still present in the OML but has decreased in intensity. Note the progressive reduction in width of the OML after ECL (compare $b, d$, and $f$ ). Scale bars: $a, b, d, f, 250 \mu \mathrm{m} ; c, e, 50 \mu \mathrm{m}$; inset in $e, 12.5 \mu \mathrm{m}$. 
sional reduction in the width of the OML (Fig. 1b,d,f). Similar changes in CNTF expression were observed in the stratum lacunosum moleculare of the ipsilateral hippocampus, which represents another target area of the lesioned entorhinal neurons (Fig. 1d,f).

\section{CNTFR $\alpha$ mRNA expression is induced in astrocytes of the OML after ECL}

As shown previously, expression of CNTFR $\alpha$ in the hippocampus of normal rats is localized exclusively to neurons of the granule cell layer of the dentate gyrus and the pyramidal cell layer of the hippocampus proper (Lee et al., 1996; MacLennan et al., 1996). In situ hybridization using a digoxigenin-labeled antisense probe for CNTFR $\alpha$ revealed that this normal expression pattern remained unchanged $4 \mathrm{hr}$ after ECL (Fig. 2a). In particular, no labeling was detectable in the molecular layer. Routinely, parallel sections were hybridized to a sense-stranded probe to assess the specificity of the labeling. This is demonstrated in Figure $2 b$ (4 hr postlesion).

Three days after ECL, numerous CNTFR $\alpha$-expressing cells appeared in the molecular layer of the ipsilateral dentate gyrus (Fig. 2d). Contralateral to the lesion, the labeling intensity and the number of stained cellular profiles were considerably lower (Fig. $2 c$ ). CNTFR $\alpha$ transcripts were specifically localized to the cytoplasm of cells in the OML; only rarely could labeled cells be observed in the IML (Fig. 2d,e).

ECLs cause a reactive increase in GFAP expression in astrocytes of the OML (Steward et al., 1990, 1993), and the labeling pattern for CNTFR $\alpha$ was reminiscent of the distribution of these reactive astrocytes, as could be demonstrated by GFAP immunocytochemistry after ECL (Fig. 3a,b). In controls, GFAP-positive astrocytes with prominently labeled processes were distributed throughout the molecular layer, with no distinct differences between the IML and OML (Fig. $3 a$ ). Three days after ECL, GFAP immunoreactivity had increased markedly in processes and cell bodies of astrocytes in the denervated OML, and a border became discernible between the IML and OML (Fig. 3b). Double labeling for GFAP protein and CNTFR $\alpha$ mRNA revealed that the cells that upregulate $\mathrm{CNTFR} \alpha$ expression in response to ECL are indeed astrocytes (Fig. $3 c-f$ ). Moreover, with the GFAP immunoreactivity clearly delineating the border between the IML and OML (Fig. 3c), it was possible to localize more precisely the position of the CNTFR $\alpha$-expressing cells within the molecular layer. In the OML, the great majority of GFAP-positive astrocytes also displayed the hybridization signal for CNTFR $\alpha$ mRNA (Fig. $3 c, d)$. Interestingly, some astrocytes with their somata located in the IML but with their processes extending into the OML were also found to be CNTFR $\alpha$ mRNA-positive (Fig. 3d,f), whereas astrocytes without contact to the denervated zone were not labeled. The phosphatase reaction product of the in situ hybridization quenched the subsequent immunocytochemical staining for GFAP, especially within the cell somata (compare Fig. $3 b$ and $c$ ). With higher magnification, however, it was clear that the two signals were colocalized in the same cells, with the CNTFR $\alpha$ transcripts confined to the cytoplasm and the GFAP immunoreactivity localized mainly in the processes (Fig. 3e,f).

On the fifth day postlesion, the staining pattern for CNTFR $\alpha$ mRNA was virtually identical to that described above for the third day. Thereafter, in situ hybridization indicated a progressive decrease of receptor expression in the OML. Thus, $7 \mathrm{~d}$ after ECL, labeling for CNTFR $\alpha$ was considerably weaker in this layer when compared with earlier postlesional stages (Fig. $4 a, b$ ). Only a few labeled cellular profiles could be identified on the lesion side (Fig. $4 b$ ) and even lower numbers were present contralaterally (Fig. $4 a, c)$. At still later time points, no $\operatorname{CNTFR} \alpha$ transcripts were detectable throughout the molecular layer of the dentate gyrus. Sham-operated animals used as controls at all time points never showed hybridization signals different from those of unoperated controls.

\section{Changes in CNTFR $\alpha$ expression in neurons of the dentate gyrus}

In controls and rats $4 \mathrm{hr}$ postlesion, granule cells displayed prominent labeling for CNTFR $\alpha$ mRNA (Fig. 2a). At $3 \mathrm{~d}$ postlesion, this neuronal CNTFR $\alpha$ mRNA expression was still comparable to controls on both sides (Fig. $2 c, d$ ). At $7 \mathrm{~d}$ postlesion, however, CNTFR $\alpha$ expression in neurons of the granular layer, most likely granule cells, was changed significantly with marked differences between the two hemispheres (Fig. $4 a$ ). Only a very weak hybridization signal could be detected in granule cells on the lesion side, indicating a downregulation of CNTFR $\alpha$ mRNA in these neurons (Fig. $4 b, d$ ). On the contralateral side, the most conspicuous change was the heterogeneous labeling intensity in the granular layer, which was reproducibly observed at this stage (Fig. 4a,b). Clusters of granule cells showed very intense labeling for CNTFR $\alpha$ mRNA, whereas the granule cells between these clusters appeared to be labeled at or slightly below the level of unoperated controls (Fig. 4c,e; compare with Fig. 2). Thus, receptor expression seemed to be upregulated in part of the neurons and unchanged or downregulated in others.

Similar differences in receptor expression were still observed after $10 \mathrm{~d}$ postlesion, but at later stages (beyond day 14) the levels of CNTFR $\alpha$ mRNA had returned to control levels on both the ipsi- and contralateral sides. No changes in CNTFR $\alpha$ mRNA expression were observed in the dentate gyri of any of the shamoperated animals.

\section{DISCUSSION}

In the present study, we have demonstrated changes in the expression of CNTF protein and CNTFR $\alpha$ mRNA in the termination zones and in target cells of entorhino-hippocampal projection neurons after their damage by an ECL. A dramatic upregulation of both molecules was observed in reactive astrocytes of the ipsilateral OML, whereas $\mathrm{CNTFR} \alpha$ was downregulated in postsynaptic dentate gyrus neurons.

\section{Astrocytic CNTF and CNTFR $\alpha$ upregulation in areas of terminal degeneration}

We regard it as intriguing results of our study that both CNTF and its receptor are dramatically upregulated at a distance from a brain lesion and the lesion-evoked expression of both molecules is restricted to activated astrocytes. Studies on peripheral nerves have concluded that CNTF acts as a "lesion factor" that is released at the lesion site from injured Schwann cells expressing unusually high quantities of the protein in the intact nerve (Sendther et al., 1992). Apparently, this scenario is not applicable to the brain, because-with the exception of the optic nerve and the olfactory bulb-CNTF levels are very low in the intact brain (Stöckli et al., 1991; Ip et al., 1993b; Kew and Sofroniew, 1995). Accordingly, the expression was undetectable by immunocytochemistry in normal animals (Fig. 1a). We now show that high levels of CNTF are produced after a brain lesion, not only in the traumatized tissue, as suggested by previous studies (Ip et al., 1993b; Asada et al., 1995), but also in the remote region of terminal degeneration. Moreover, we could unequivocally localize 

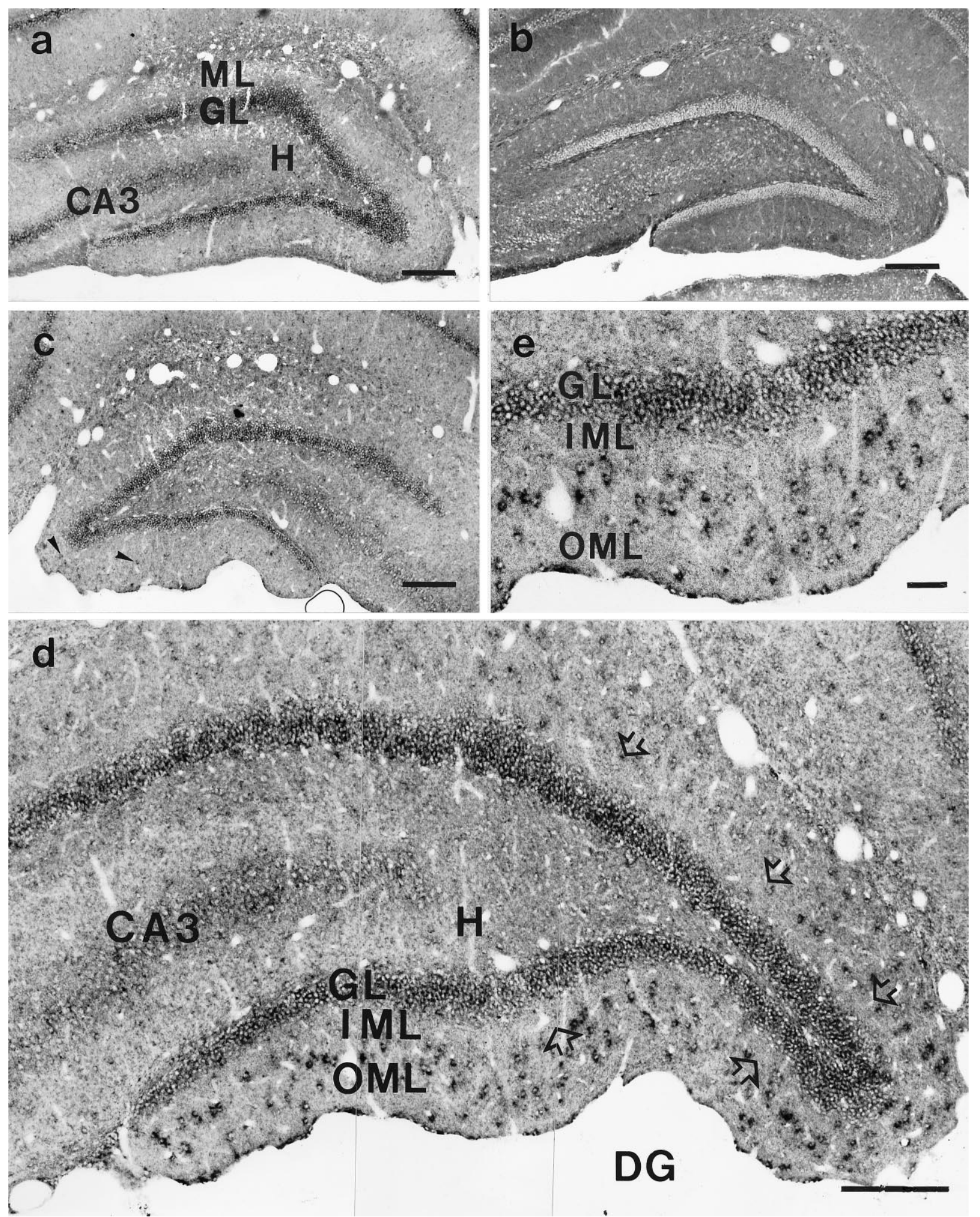

Figure 2. Changes in CNTFR $\alpha$ mRNA expression $3 \mathrm{~d}$ after ECL. $a$, Section of the dentate gyrus from a lesioned animal (4 hr postlesion; ipsilateral to the lesion) hybridized to antisense-stranded probe for CNTFR $\alpha$. The OML of the dentate gyrus is devoid of CNTFR $\alpha$ mRNA. The hybridization signal is confined to neurons in the granule cell and pyramidal cell layer $(G L, C A 3)$. $H$, Hilus. $b$, Control section stained with a sense-stranded probe. $c$, Dentate gyrus contralateral to an ECL $3 \mathrm{~d}$ postlesion. Very few cells are visible in the OML that are positive for CNTFR $\alpha$ mRNA (arrowheads). $d$, Dentate gyrus ipsilateral to an ECL 3 d postlesion. Numerous labeled cells are present in the OML, whereas cells are labeled only occasionally in the IML. The open arrows point to the border between the heavily labeled OML and the sparsely labeled IML. $e$, Higher magnification of a portion of the infrapyramidal blade of the dentate gyrus shown in $d$. Note the numerous profiles of labeled cells in the OML of the dentate gyrus and the clear demarcation from the IML. Scale bars: $a-c, 250 \mu \mathrm{m} ; d, 200 \mu \mathrm{m} ; e, 50 \mu \mathrm{m}$. 

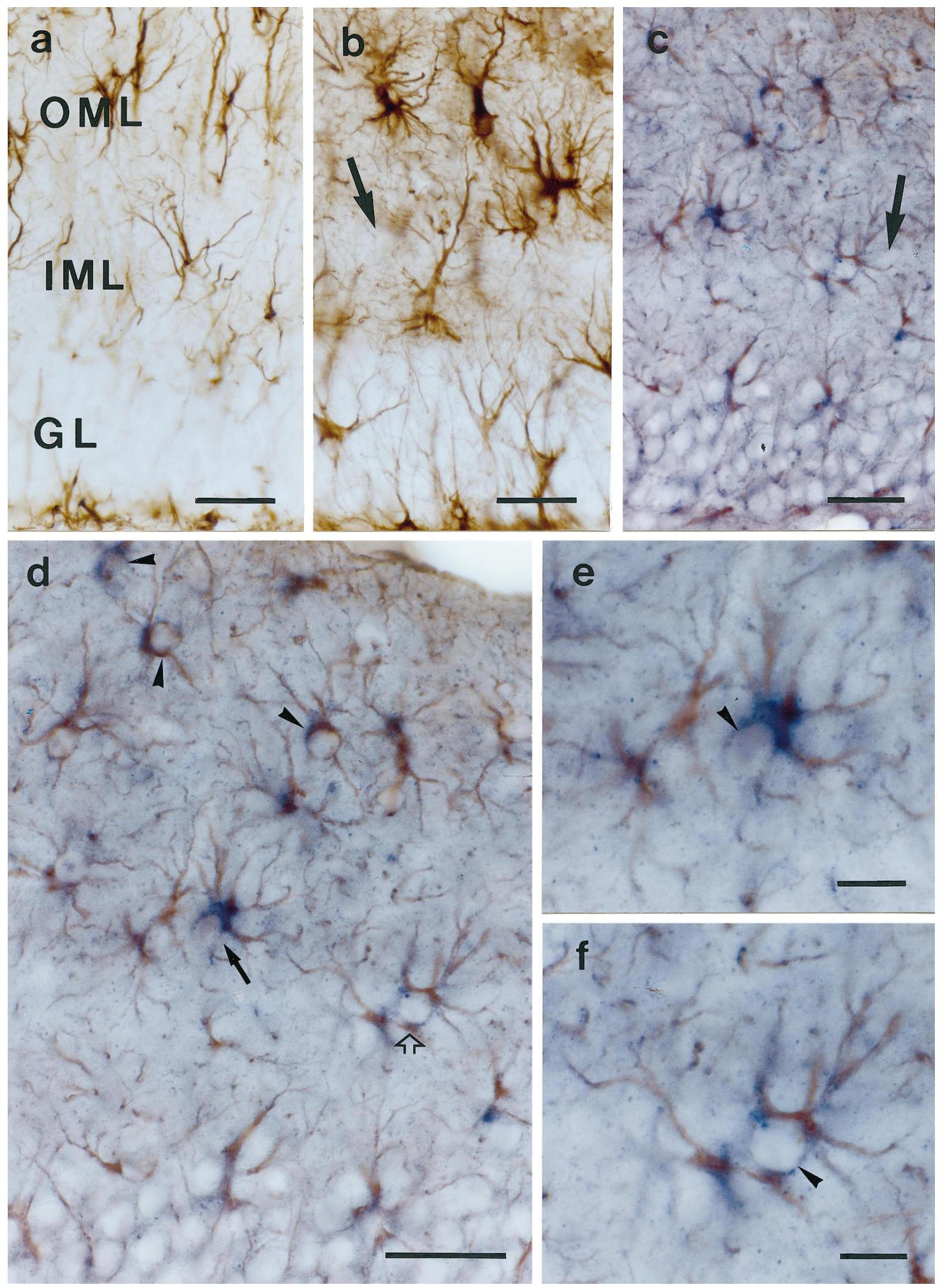

Figure 3. Identification of CNTFR $\alpha$-expressing astrocytes in the denervated OML. $a$, GFAP immunoreactivity in the molecular layer of the dentate gyrus in a control animal. $b$, GFAP immunoreactivity $3 \mathrm{~d}$ after ECL. Note the increase in GFAP-staining in the denervated OML. The arrow points to the border between the IML and the OML. $c$, Double labeling for GFAP (immunocytochemistry) and CNTFR $\alpha$-mRNA (in situ hybridization). Although immunoreactivity is slightly quenched by the hybridization signal, the pattern of GFAP immunostaining is similar to that shown in $b$. The arrow points to the border between the IML and the OML. $d$, Higher magnification of the molecular layer from $c$. Note that most astrocytes (Figure legend continues) 
the CNTF immunoreactivity to reactive astrocytes. This demonstrates that the upregulation of CNTF production as observed in astrocytic cultures (Stöckli et al., 1991; Rudge et al., 1992, 1994b; Carroll et al., 1993) also occurs in vivo in response to lesionevoked signals. Our double-labeling experiments suggest that the same population of reactive astrocytes is also induced to express CNTFR $\alpha$ mRNA and provide direct evidence that astrocytes in the lesioned CNS not only synthesize large amounts of the neurotrophic factor but also express the relevant receptor. The expression of the three CNTF receptor components and autophosphorylation responses to CNTF have been shown in astrocyte cultures, demonstrating that the functional high-affinity CNTF receptor complex can be produced by astrocytes (Rudge et al., 1994a, 1995). Our in vivo observation of the simultaneous expression of CNTF and its receptor in astrocytes also producing high levels of GFAP suggests that CNTF functions as a paracrine or autocrine signal for astrocytes in the course of reactive changes occurring after injury.

\section{Is there a role for CNTF in sprouting and reactive synaptogenesis?}

After ECL, up to $90 \%$ of the afferent synapses to the rat fascia dentata are lost. Other surviving afferents sprout and replace the entorhinal input (Matthews et al., 1976a,b; Steward and Vinsant, 1983). The time course of the degeneration and reinnervation process has been analyzed in detail using electron microscopy (Matthews et al., 1976a,b; Lee et al., 1977; Hoff et al., 1982; Steward and Vinsant, 1983). Most synapses in the OML are lost within $2 \mathrm{~d}$ postlesion, followed by a massive proliferation of presynaptic terminals between 4 and $14 \mathrm{~d}$ and by the appearance of new synapses slightly later (Steward and Vinsant, 1983; Steward, 1991). Similarly, the time course of glial changes occurring after ECL is known (Gage et al., 1988; Steward et al., 1990, 1993; Kelley and Steward, 1996a,b): GFAP mRNA expression increases within $1 \mathrm{~d}$ postlesion and GFAP protein follows by $2 \mathrm{~d}$ postlesion (Steward et al., 1993). By 10 d, GFAP mRNA and protein decline and return to control levels by $30 \mathrm{~d}$. Moreover, granule cell dendrites are remodelled after ECL. This transneuronal effect begins around $8 \mathrm{~d}$ postlesion and is complete by $14 \mathrm{~d}$ (Caceres and Steward, 1983).

The presently observed increase in CNTF and CNTFR $\alpha$ expression after ECL paralleled that of GFAP immunoreactivity during the first $3 \mathrm{~d}$ after the lesion, but the upregulation of GFAP is sustained for longer periods. Interestingly, the distribution pattern of CNTF immunoreactivity changed from an almost homogeneous staining throughout the OML (day 3 postlesion) to a cellular staining of astrocytes (day 7 postlesion), suggesting that changes in the distribution of CNTF occur during this time period. Previous studies (Stöckli et al., 1989, 1991; Dobrea et al., 1992), together with our results, suggest that glial cells are the only source for CNTF, making it likely that the more diffuse but layer-specific increase of CNTF immunoreactivity observed at early postlesional stages is also attributable to an increase in CNTF production by astrocytes. To prove this assumption and to investigate the significance of the changing CNTF distribution, it will be necessary to perform an electron microscopic study. Our present results show that the availability of CNTF in the OML and the potential CNTF responsiveness of astrocytes is maximal during early phases of reinnervation. This close correlation suggests that CNTF is involved in the regulation of astrocyte function associated with this restorative process; however, because the OML also contains neuronal target structures for CNTF, other possible roles for CNTF are conceivable. For example, some of the cells of origin of the sprouting fibers do strongly express CNTFR $\alpha$ mRNA in control animals (Lee et al., 1996; MacLennan et al., 1996). This indicates that CNTF may also have a direct action on the sprouting axons, because bouton proliferation begins shortly after the time CNTF is upregulated in the denervated OML. Likewise, CNTFR $\alpha$ mRNA is present in granule cells, and CNTFR $\alpha$ mRNA changes that occur between 7 and $10 \mathrm{~d}$ postlesion correlate nicely with the time period of lesion-induced dendritic remodeling in granule cells. Therefore, a direct effect of CNTF on the deafferented granule cells may also exist. The observed changes in CNTFR $\alpha$ mRNA in the contralateral granule cell layer, which receives only minor input from the lesioned entorhinal cortex, is difficult to interpret; however, ECL-induced regulatory responses in the contralateral dentate gyrus have also been observed for other molecules, e.g., for GFAP (Steward et al., 1993),

\section{Does neuron-astrocyte interaction regulate CNTF and CNTFR $\alpha$ expression?}

Our results raise the question regarding the regulatory signals responsible for the massive layer-specific upregulation of CNTF and CNTFR $\alpha$. Neurotrophins have also been shown to be upregulated after different kinds of lesions, including ECL (Persson, 1993; Gwag et al., 1994). The fast or rapid- and short-lasting (1-2 d) upregulation of neurotrophin mRNA is mediated by excitatory neurotransmitter receptors in response to an excess of transmitter released from the terminals of damaged afferents (Gall et al., 1991; Thoenen et al., 1991; Gwag et al., 1993). These early changes are unlikely to be related to the reorganization processes occurring only several days later (Lapchak et al., 1993) (E. Förster, T. Deller, and M. Frotscher, unpublished data). When compared with the neurotrophins, upregulation of CNTF is delayed considerably and sustained for much longer periods, indicating different regulatory mechanisms. In fact, administration of transmitter agonists did not increase CNTF levels in glial cultures (Carroll et al., 1993; Rudge et al., 1994b). Rather, they were markedly reduced by adenylyl cyclase activating agonists. Recently, Rudge et al. (1995) showed in an elegant in vitro study that CNTF expression by astrocytes is downregulated by $\sim 90 \%$ within 1 week after seeding of hippocampal neurons onto the glial cultures. Subsequent induction of neuronal cell death by administration of kainic acid resulted in a reupregulation of CNTF in the astrocytes within 2-3 d, and this was accompanied by the appearance of functional CNTF receptors. These observations suggest that the close association of astrocytes with neurons in the normal brain results in a permanent suppression of CNTF and CNTFR $\alpha$ expression, and that the loss of contact with neurons or

are positive for CNTFR $\alpha$ mRNA (arrowheads). The double-labeled astrocyte indicated with a bold arrow is located in the OML, whereas the double-labeled astrocyte indicated with an open arrow is located in the IML, with its processes extending into the OML. These cells are shown in $e$ and $f$, respectively. $e$, Higher magnification of the cell indicated with a bold arrow in $d$. Note the GFAP-immunoreactive processes (brown) and the CNTFR $\alpha$-mRNA signal (blue) in the perinuclear cytoplasm (arrowhead). $f$, Higher magnification of the cell indicated with an open arrow in $d$. Note the GFAP-immunoreactive processes (brown) that lie in the denervated zone of the molecular layer, whereas the soma exhibiting the hybridization signal for CNTFR $\alpha$ is located in the IML (arrowhead). Scale bars: $a-d, 50 \mu \mathrm{m} ; e, f, 25 \mu \mathrm{m}$. 

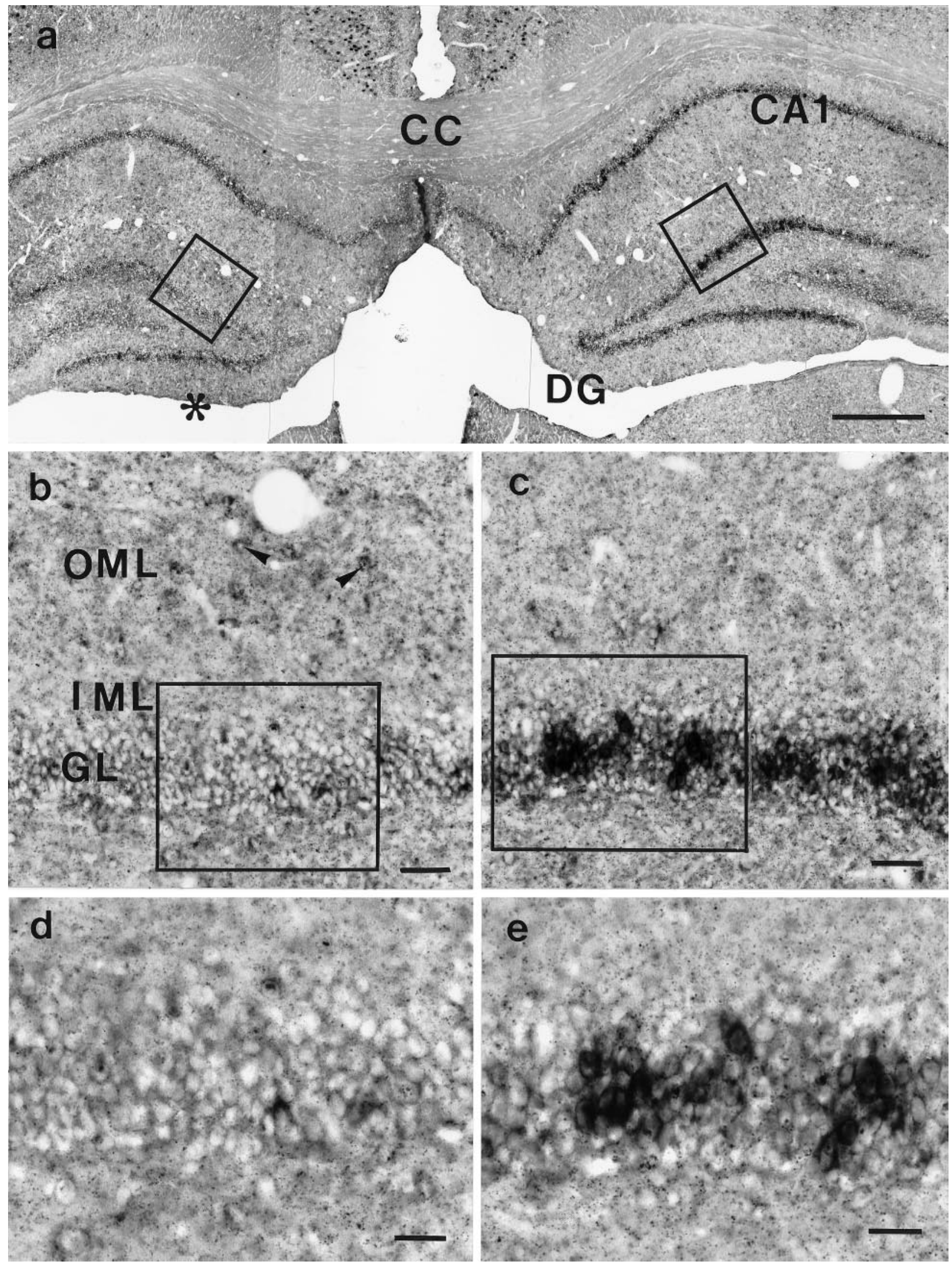

Figure 4. Expression of CNTFR $\alpha$ mRNA in dentate gyrus neurons and glial cells $7 \mathrm{~d}$ postlesion. $a$, Coronal section through the brain showing both dentate gyri. Labeling for CNTFR $\alpha$ mRNA is much weaker in granule cells on the side of the lesion (asterisk). $b$, Higher magnification of the left rectangle in $a$. CNTFR $\alpha$ mRNA levels are very low in the granule cell layer compared to the contralateral side (compare with $c$ ). Note that labeling of astrocytes in the OML has decreased markedly at this time point (compare with Fig. 2e). Some labeled cells are marked by arrowheads. Figure legend continues. 
their processes leads to an upregulation of the proteins. The results of our in vivo study fit nicely with this hypothesis. Loss of the main afferents to the OML during the first $2 \mathrm{~d}$ after ECL would cause the upregulation of $\operatorname{CNTF}$ and $\operatorname{CNTFR} \alpha$, and in the course of reinnervation 4-14 d postlesion, this upregulation would become resuppressed by sprouting fibers. Even the time course of the CNTF changes in the OML was compatible with that observed in the in vitro experiments (Rudge et al., 1995).

\section{CNTF is unlikely to be released by dying cells of the OML}

Another question concerns the functional significance of the upregulation of $\mathrm{CNTF}$ and $\mathrm{CNTFR} \alpha$. The neurotrophic protein contains no signal sequence that would allow its secretion by the classical vesicular mechanism (Stöckli et al., 1989), and several studies have failed to demonstrate the release of significant amounts of the protein by cultured CNTF-expressing cells (Lillien et al., 1988; Lin et al., 1989; Stöckli et al., 1989; Rudge et al., 1995). This has fostered the assumption that the factor can be released only from damaged or dying CNTF-producing cells, e.g., Schwann cells of the injured peripheral nerve or astrocytes at wound sites in the CNS; however, there is no indication that terminal degeneration or reinnervation in the OML after ECL is accompanied by the death of astrocytes, which could lead to the this kind of release. Thus, one has to postulate that CNTF can be released into the extracellular space by intact astrocytes. Recently, evidence has been presented for the release of CNTF by cultured astrocytes that could be stimulated by exogenous cytokines, e.g., by IL-1 and TNF- $\alpha$ (Kamiguchi et al., 1995). Interestingly, these two peptides are both produced by microglial cells and astrocytes (Benveniste, 1995) and are upregulated in the hippocampus after injury (Hayes et al., 1995). In our study, CNTF immunoreactivity displayed a relatively homogeneous distribution $3 \mathrm{~d}$ postlesion, which differed substantially from the clearly intracellular localization observed at later stages. These observations make it tempting to speculate that lesion-induced cues-possibly provided by microglial cells, which are the first to respond to deafferentation in the OML (Gehrmann et al., 1991) — can regulate the availability of astrocyte-derived CNTF in the extracellular space.

In summary, our findings suggest that CNTF and its receptor represent important components of a cascade of events occurring in the OML after deafferentation. These postlesional changes involve the interaction of different cell types, including microglia, astrocytes, sprouting fibers, and deafferented neurons. The massive but transient upregulation of CNTF and CNTFR $\alpha$ in astrocytes during the period of sprouting, bouton proliferation, and reactive synaptogenesis points to a novel important role of reactive astrocytes in the regulation of these processes.

\section{REFERENCES}

Altar CA, Armanini M, Gugich-Djordjevic M, Bennett GL, Williams R, Feinglass S, Anicetti V, Sinicropi D, Bakhit C (1992) Recovery of cholinergic phenotype in the injured rat neostriatum: roles for endogenous and exogenous nerve growth factor. J Neurochem 59:2167-2177.

Asada H, Ip NY, Pan L, Razack N, Parfitt MM, Plunkett RJ (1995) Time course of ciliary neurotrophic factor mRNA expression is coincident with the presence of protoplasmic astrocytes in traumatized rat striatum. J Neurosci Res 40:22-30.

Benveniste EN (1995) Cytokine production. In: Neuroglia (Kettenmann H, Ransom BR, eds), pp 700-713. New York: Oxford UP.

Caceres A, Steward O (1983) Dendritic reorganization in the denervated dentate gyrus of the rat following entorhinal cortex lesions: a Golgi and electron microscopic analysis. J Comp Neurol 214:387-403.

Carroll P, Sendtner M, Meyer M, Thoenen H (1993) Rat ciliary neurotrophic factor (CNTF): gene structure and regulation of mRNA levels in glial cell cultures. Glia 9:176-187.

Chromczynski P, Sacchi N (1987) Single-step method of RNA isolation by acid guanidinium thiocyanate-phenol-chloroform extraction. Anal Biochem 162:156-159.

Curtis R, Adryan KM, Zhu Y, Harkness PJ, Lindsay RM, DiStefano PS (1993) Retrograde axonal transport of ciliary neurotrophic factor is increased by peripheral nerve injury. Nature 365:253-255.

Davis S, Aldrich TH, Stahl N, Pan L, Taga T, Kishimoto T, Ip NY, Yancopoulos GD (1993) LIFR $\beta$ and gp130 as heterodimerizing signal transducers of the tripartite CNTF receptor. Science 260:1805-1808.

Deller T, Frotscher M, Nitsch R (1995) Morphological evidence for the sprouting of inhibitory commissural fibers in response to the lesion of the entorhinal input to the rat dentate gyrus. J Neurosci 15:6868-6878.

Deller T, Frotscher M, Nitsch R (1996a) Sprouting of crossed entorhinodentate fibers after unilateral entorhinal lesion: anterograde tracing of fiber reorganization with Phaseolus vulgaris-leucoagglutinin (PHAL). J Comp Neurol 365:42-55.

Deller T, Nitsch R, Frotscher M (1996b) Layer-specific sprouting of commissural fibers to the rat fascia dendata after unilateral entorhinal cortex lesion: a PHAL tracing study. Neuroscience 71:651-660.

Dobrea GM, Unnerstall JR, Rao MS (1992) The expression of CNTF message and immunoreactivity in the central and peripheral nervous system of the rat. Dev Brain Res 66:209-219.

Eddleston M, Mucke L (1993) Molecular profile of reactive astrocytes: implications for their role in neurological disease. Neuroscience 54:15-36.

Friedman B, Scherer SS, Rudge JS, Helgren M, Morrisey D, Wang XX, Wiegand SJ, Furth ME, Lindsay RM, Ip NY (1992) Regulation of ciliary neurotrophic factor expression in myelin-related Schwann cells in vivo. Neuron 9:295-305.

Gage FH, Olejnizcak P, Armstrong DM (1988) Astrocytes are important for sprouting in the septohippocampal circuit. Exp Neurol 102:2-13.

Gall C, Murray K, Isackson P (1991) Kainic acid-induced seizures stimulate increased expression of nerve growth factor mRNA in rat hippocampus. Mol Brain Res 9:113-123.

Gehrmann J, Schoen SW, Kreutzberg GW (1991) Lesion of the rat entorhinal cortex leads to a rapid microglial reaction in the dentate gyrus. Acta Neuropathol 82:442-455.

Gwag BJ, Sessler FM, Waterhouse BD, Springer JE (1993) Regulation of nerve growth factor mRNA in the hippocampal formation: effects of $N$-methyl-D-aspartate receptor activation. Exp Neurol 121:160-171.

Gwag BJ, Sessler F, Kimmerer K, Springer JE (1994) Neurotrophic factor mRNA expression in the dentate gyrus is increased following angular bundle transection. Brain Res 647:23-29.

Hayes RL, Yang K, Raghupathi R, McIntosh TK (1995) Changes in gene expression following traumatic brain injury in the rat. J Neurotrauma 12:779-790.

Hoff SF, Scheff SW, Bernardo LS, Cotman CW (1982) Lesion-induced synaptogenesis in the dentate gyrus of aged rats. I. Loss and reacquisition of normal synaptic density. J Comp Neurol 205:246-252.

Ip NY, McClain J, Barrezueta NX, Aldrich TH, Pan L, Li Y, Wiegand SJ, Friedman B, Davis S, Yancopoulos GD (1993a) The $\alpha$ component of the CNTF receptor is required for signaling and defines potential CNTF targets in the adult and during development. Neuron 10:89-102.

Ip NY, Wiegand SJ, Morse J, Rudge JS (1993b) Injury-induced regulation of ciliary neurotrophic factor mRNA in the adult rat brain. Eur J Neurosci 5:25-33.

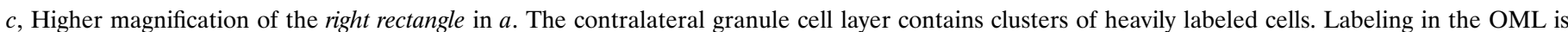

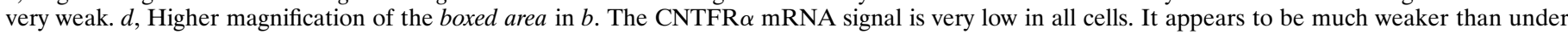

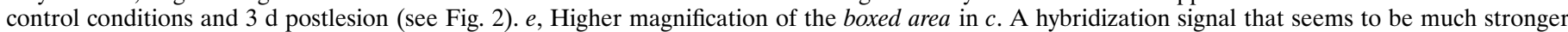

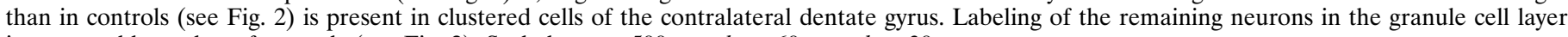
is comparable to that of controls (see Fig. 2). Scale bars: $a, 500 \mu \mathrm{m} ; b, c, 60 \mu \mathrm{m} ; d, e, 30 \mu \mathrm{m}$. 
Kamiguchi H, Yoshida K, Sago M, Sasaki H, Inaba M, Wakamoto H, Otani M, Toya S (1995) Release of ciliary neurotrophic factor from cultured astrocytes and its modulation by cytokines. Neurochem Res 20:1187-1193.

Kelley MS, Steward O (1996a) The process of reinnervation in the dentate gyrus of adult rats: physiological events at the time of the lesion and during the early postlesion period. Exp Neurol 139:73-82.

Kelley MS, Steward O (1996b) The role of postlesion seizures and spreading depression in the upregulation of glial fibrillary acidic protein mRNA after entorhinal cortex lesions. Exp Neurol 139:83-94.

Kew JNC, Sofroniew MV (1995) Ciliary neurotrophic factor supports p75NGFR-immunoreactive non-cholinergic, but not cholinergic, developing septal neurons in vitro. Neuroscience 66:793-804.

Kirsch M, Hofmann H-D (1994) Expression of ciliary neurotrophic factor receptor mRNA and protein in the early postnatal and adult rat nervous system. Neurosci Lett 180:163-167.

Lapchak PA, Araujo DM, Hefti F (1993) BDNF and trkB mRNA expression in the rat hippocampus following entorhinal cortex lesions. NeuroReport 4:191-194.

Lee KS, Stanford EJ, Cotman CW, Lynch GS (1977) Ultrastructural evidence for bouton proliferation in the partially deafferentiated dentate gyrus of the adult rat. Exp Brain Res 29:475-485.

Lee M-Y, Hofmann H-D, Kirsch M (1996) Expression of ciliary neurotrophic factor receptor $\alpha$ mRNA in neonatal and adult rat brain: an in situ hybridization study. Neuroscience, in press.

Lillien LE, Sendtner M, Rohrer H, Hughes SM, Raff MC (1988) Type-2 astrocyte development in rat brain cultures is initiated by a CNTF-like protein produced by type-1 astrocytes. Neuron 1:485-494.

Lin L-FH, Mismer D, Lile JD, Armes LG, Butler ET, Vannice JL, Collins F (1989) Purification, cloning, and expression of ciliary neurotrophic factor (CNTF). Science 246:1023-1025.

Lindsay RM (1979) Adult rat brain astrocytes support survival of both NGF-dependent and NGF-insensitive neurons. Nature 282:80-82.

Lindsay RM, Wiegand SJ, Altar CA, DiStefano PS (1994) Neurotrophic factors: from molecule to man. Trends Neurosci 17:182-190.

Longo FM, Holtzman DM, Grimes ML, Mobley WC (1993) Nerve growth factor: actions in the peripheral and central nervous system. In: Neurotrophic factors (Loughlin SE, Fallon JH, eds), pp 209-256. San Diego: Academic.

Lu B, Yokoyama M, Dreyfus CF, Black IB (1991) NGF gene expression in actively growing brain glia. J Neurosci 11:318-326.

MacLennan AJ, Vinson EN, Marks L, McLaurin D, Pfeifer M, Lee N (1996) Immunohistochemical localization of ciliary neurotrophic factor receptor $\alpha$ expression in the rat nervous system. J Neurosci 16:621-630.

Manthorpe M, Skaper SD, Williams RL, Varon S (1986) Purification of adult rat sciatic nerve ciliary neuronotrophic factor. Brain Res 367:282-286.

Manthorpe M, Louis J-L, Hagg T, Varon S (1993) Ciliary neuronotrophic factor. In: Neurotrophic factors (Loughlin SE, Fallon JH, eds), pp 443-473. San Diego: Academic.

Matthews DA, Cotman CW, Lynch G (1976a) An electron microscopic study of lesion-induced synaptogenesis in the dentate gyrus of the adult rat. I. Magnitude and time course of degeneration. Brain Res 115:1-21.

Matthews DA, Cotman CW, Lynch G (1976b) An electron microscopic study of lesion-induced synaptogenesis in the dentate gyrus of the adult rat. II. Reappearance of morphologically normal synaptic contacts. Brain Res 115:23-41.

Nieto-Sampedro M, Bovolenta P (1990) Growth factors and growth factor receptors in the hippocampus: role in plasticity and response to injury. Prog Brain Res 83:341-355.

Paxinos G, Watson C (1986) Atlas of the rat brain in stereotaxic coordinates. Sydney: Academic.
Persson H (1993) Neurotrophin production in the brain. Semin Neurosci 5:227-237.

Rudge JS, Alderson RF, Pasnikowski EM, McClain J, Ip NY, Lindsay RM (1992) Expression of ciliary neurotrophic factor and the neurotrophinsnerve growth factor, brain-derived neurotrophic factor and neurotrophin 3-in cultured rat hippocampal astrocytes. Eur J Neurosci 4:459-471.

Rudge JS, Li Y, Pasnikowski EM, Mattsson K, Pan L, Yancopoulos GD, Wiegand SJ, Lindsay RM, Ip NY (1994a) Neurotrophic factor receptors and their signal transduction in rat astrocytes. Eur $\mathbf{J}$ Neurosci 6:693-705.

Rudge JS, Morrissey D, Lindsay RM, Pasnikowski EM (1994b) Regulation of ciliary neurotrophic factor in cultured rat hippocampal astrocytes. Eur J Neurosci 6:218-229.

Rudge JS, Pasnikowski EM, Holst P, Lindsay RM (1995) Changes in neurotrophic factor expression and receptor activation following exposure of hippocampal neuron/astrocyte cocultures to kainic acid. J Neurosci 15:6856-6867.

Sendtner M, Stöckli KA, Thoenen H (1992) Synthesis and localization of ciliary neurotrophic factor in the sciatic nerve of the adult rat after lesion and during regeneration. J Cell Biol 118:139-148.

Sendtner M, Carroll P, Holtmann B, Hughes RA, Thoenen H (1994) Ciliary neurotrophic factor. J Neurobiol 25:1436-1453.

Sofroniew MV, Cooper JD (1993) Neurotrophic mechanisms and neuronal degeneration. Semin Neurosci 5:285-294.

Stahl N, Davis S, Wong V, Taga T, Kishimoto T, Ip NY, Yancopoulos GD (1993) Cross-linking identifies leukemia inhibitory factor-binding protein as a ciliary neurotrophic factor receptor component. J Biol Chem 268:7628-7631.

Steward O (1991) Synapse replacement on cortical neurons following denervation. Cereb Cortex 9:81-132.

Steward O (1994) Reorganization of neuronal circuitry following central nervous system trauma: naturally occurring processes and opportunities for therapeutic intervention. In: The neurobiology of central nervous system trauma (Salzman SK, Faden AI, eds), pp 266-287. New York: Oxford UP.

Steward O, Vinsant SL (1983) The process of reinnervation in the dentate gyrus of the adult rat: a quantitative electron microscopic analysis of terminal proliferation and reactive synaptogenesis. J Comp Neurol 214:370-386.

Steward O, Torre ER, Trimmer PA (1990) The process of reinnervation in the dentate gyrus of adult rats: time course of increase in mRNA for glial fibrillary acidic protein. J Neurosci 10:2373-2384.

Steward O, Kelly MS, Torre ER (1993) The process of reinnervation in the dentate gyrus of adult rats: temporal relationship between changes in the levels of glial fibrillary acidic protein (GFAP) and GFAP mRNA in reactive astrocytes. Exp Neurol 124:167-183.

Stöckli KA, Lottspeich F, Sendtner M, Masiakowski P, Carroll P, Götz R, Lindholm D, Thoenen H (1989) Molecular cloning, expression and regional distribution of rat ciliary neurotrophic factor. Nature 342:920-923.

Stöckli KA, Lillien LE, Näher-Noé M, Breitfeld G, Hughes RA, Raff MC, Thoenen H, Sendtner M (1991) Regional distribution, developmental changes, and cellular localization of CNTF-mRNA and protein in the rat brain. J Cell Biol 115:447-459.

Thoenen H, Zafra F, Hengerer B, Lindholm D (1991) The synthesis of nerve growth factor and brain-derived neurotrophic factor in hippocampal and cortical neurons is regulated by specific transmitter systems. Ann NY Acad Sci 640:86-90.

Yoshida K, Gage FH (1992) Cooperative regulation of nerve growth factor synthesis and secretion in fibroblasts and astrocytes by fibroblast growth factor and other cytokines. Brain Res 569:14-25. 